\title{
Hypochlorous acid and hydrogen peroxide-induced negative regulation of Salmonella enterica serovar Typhimurium ompW by the response regulator ArcA
}

Eduardo H Morales ${ }^{1 \dagger}$, Iván L Calderón ${ }^{1 \dagger}$, Bernardo Collao ${ }^{1}$, Fernando Gil ${ }^{1}$, Steffen Porwollik², Michael McClelland ${ }^{2,3}$ and Claudia P Saavedra ${ }^{1 *}$

\begin{abstract}
Background: Hydrogen peroxide $\left(\mathrm{H}_{2} \mathrm{O}_{2}\right)$ and hypochlorous acid $(\mathrm{HOCl})$ are reactive oxygen species that are part of the oxidative burst encountered by Salmonella enterica serovar Typhimurium (S. Typhimurium) upon internalization by phagocytic cells. In order to survive, bacteria must sense these signals and modulate gene expression. Growing evidence indicates that the ArcAB two component system plays a role in the resistance to reactive oxygen species. We investigated the influx of $\mathrm{H}_{2} \mathrm{O}_{2}$ and $\mathrm{HOCl}$ through $\mathrm{OmpW}$ and the role of ArcAB in modulating its expression after exposure to both toxic compounds in S. Typhimurium.

Results: $\mathrm{H}_{2} \mathrm{O}_{2}$ and $\mathrm{HOCl}$ influx was determined both in vitro and in vivo. A S. Typhimurium ompW mutant strain ( $\triangle$ ompW exposed to sub-lethal levels of $\mathrm{H}_{2} \mathrm{O}_{2}$ and $\mathrm{HOCl}$ showed a decreased influx of both compounds as compared to a wild type strain. Further evidence of $\mathrm{H}_{2} \mathrm{O}_{2}$ and $\mathrm{HOCl}$ diffusion through $\mathrm{OmpW}$ was obtained by using reconstituted proteoliposomes. We hypothesized that ompW expression should be negatively regulated upon exposure to $\mathrm{H}_{2} \mathrm{O}_{2}$ and $\mathrm{HOCl}$ to better exclude these compounds from the cell. As expected, qRT-PCR showed a negative regulation in a wild type strain treated with sub-lethal concentrations of these compounds. A bioinformatic analysis in search for potential negative regulators predicted the presence of three ArcA binding sites at the ompW promoter region. By electrophoretic mobility shift assay (EMSA) and using transcriptional fusions we demonstrated an interaction between ArCA and one site at the ompW promoter region. Moreover, qRT-PCR showed that the negative regulation observed in the wild type strain was lost in an $\operatorname{arc} A$ and in $\operatorname{arcB}$ mutant strains.
\end{abstract}

Conclusions: $\mathrm{OmpW}$ allows the influx of $\mathrm{H}_{2} \mathrm{O}_{2}$ and $\mathrm{HOCl}$ and is negatively regulated by ArcA by direct interaction with the ompW promoter region upon exposure to both toxic compounds.

\section{Background}

Hydrogen peroxide $\left(\mathrm{H}_{2} \mathrm{O}_{2}\right)$ and hypochlorous acid $(\mathrm{HOCl})$ are reactive oxygen species that are part of the oxidative burst encountered by $S$. Typhimurium upon internalization by phagocytic cells. Under acidic conditions, such as those found inside the phagosome, $\mathrm{H}_{2} \mathrm{O}_{2}$ is generated spontaneously by the reaction of two superoxide anion $\left(\mathrm{O}_{2}^{-}\right)$molecules [1]. Moreover, S. Typhimurium encodes both

\footnotetext{
*Correspondence: csaavedra@unab.cl

${ }^{\dagger}$ Equal contributors

'Laboratorio de Microbiología Molecular, Facultad Ciencias Biológicas, Universidad Andres Bello, Santiago, Chile

Full list of author information is available at the end of the article
}

periplasmic and cytoplasmic superoxide dismutases that catalyze $\mathrm{O}_{2}^{-}$dismutation to generate $\mathrm{H}_{2} \mathrm{O}_{2}$ and molecular oxygen [2-4]. $\mathrm{HOCl}$ is produced by the action of myeloperoxidase (MPO) in a reaction that depends on $\mathrm{H}_{2} \mathrm{O}_{2}, \mathrm{Cl}$ -and acidic conditions $[5,6]$. Taken together, $\mathrm{H}_{2} \mathrm{O}_{2}$ and $\mathrm{HOCl}$ react with thiol and heme groups, copper and iron salts generating the reactive hydroxyl radical $(\mathrm{OH})$. As a consequence, they produce lipid peroxidation, chlorination of tyrosine residues, oxidation of iron centers, protein cross linking and DNA damage [5-8].

In order to enter Gram negative bacteria, $\mathrm{H}_{2} \mathrm{O}_{2}$ and $\mathrm{HOCl}$ must be able to cross the outer membrane $(\mathrm{OM})$ and even though several biological membranes are 
permeable to $\mathrm{H}_{2} \mathrm{O}_{2}$, studies in E. coli and Saccharomyces cerevisiae showed that this compound cannot diffuse freely $[9,10]$. For $\mathrm{HOCl}$, diffusion through the $\mathrm{OM}$ is reported to be limited [11]. One possibility for $\mathrm{H}_{2} \mathrm{O}_{2}$ and $\mathrm{HOCl}$ influx through the $\mathrm{OM}$ is diffusion through porins. In this context, we recently reported that $\mathrm{OmpD}, \mathrm{S}$. Typhimurium most abundant $\mathrm{OM}$ porin, allows $\mathrm{H}_{2} \mathrm{O}_{2}$ diffusion [12]. OM porins are organized as homo-trimers (classic porins) or monomers (small porins) forming aqueous channels that allow the influx of hydrophilic solutes with a molecular weight $\leq 600 \mathrm{Da}$ [13]. Classic porins, including OmpC and OmpF, form $\beta$-barrels with 12-22 transmembrane segments while small porins $(\mathrm{OmpW})$ are composed of $8-$ 10 [14,15]. The crystal structure of OmpW from E. coli revealed that it forms an 8 -stranded $\beta$-barrel and functions as an ion channel in lipid bilayers [16,17]. In Vibrio cholerae, OmpW was described as an immunogenic $22 \mathrm{KDa}$ protein [18] and its expression is altered by factors such as temperature, salinity, nutrient availability and oxygen levels [19]. Additionally, several studies show that porins are regulated by ROS. Due its oxidant nature and diffusion through the $\mathrm{OM}$, regulation of porin expression must be tightly regulated as a mechanism of controlling OM permeability. Accordingly, $S$. Typhimurium ompD and $o m p W$ expression is regulated in response to $\mathrm{H}_{2} \mathrm{O}_{2}$ and paraquat $[12,20]$, respectively, and $S$. Enteritidis and Typhimurium exposure to $\mathrm{HOCl}$ results in lower levels of $о m p D, o m p C$ and $o m p F$ transcripts [21].

The cellular response to oxidative stress is regulated at the transcriptional level by activating the SoxRS and OxyR regulons in response to $\mathrm{O}_{2}^{-}$and $\mathrm{H}_{2} \mathrm{O}_{2}$, respectively $[22,23]$, however, several studies have provided evidence for a role of the ArcAB two component system in the resistance to ROS induced damage [12,24-26]. ArcA is essential for $S$. Enteritidis, Typhimurium and $E$. coli resistance to $\operatorname{ROS}[24,26,27]$. ArcB is a sensor member of the histidine kinase family that is anchored to the inner membrane [28]. In response to oxygen availability, ArcB autophosphorylates in an ATP dependant intramolecular reaction at position His-292 [29,30] and transfers the phosphate group to the cytoplasmic response regulator ArcA [31-33], which binds to promoter regions regulating gene expression $[34,35]$. ArcB activity is regulated in response to oxygen conditions by the redox state of both the ubiquinone and menaquinone pools [29,36-38]. However, recent studies in E. coli show that the system is regulated by the degree of aerobiosis but not by the redox state of the ubiquinone pool, challenging the idea that the system is inhibited by oxidized quinones [39].

In this work we provide further evidence of the role of the $\mathrm{ArcAB}$ two component system in the response to ROS under aerobic conditions and show that this system mediates regulation of omp $W$ expression in response to a novel signal, $\mathrm{HOCl}$. First we demonstrate, both in vivo and in vitro, that $\mathrm{OmpW}$ mediates diffusion of $\mathrm{H}_{2} \mathrm{O}_{2}$ and $\mathrm{HOCl}$ and that exposure of $S$. Typhimurium to these compounds results in a negative regulation of omp W. By EMSA and using transcriptional fusions, we demonstrate that the global regulator ArcA binds to the ompW promoter region. Furthermore, we show that ompW negative regulation observed in wild type cells treated with $\mathrm{H}_{2} \mathrm{O}_{2}$ and $\mathrm{HOCl}$ was not retained in an $\operatorname{arc} A$ or $\operatorname{arcB}$ mutant strain, indicating that the $\operatorname{Arc} A B$ two component system mediates omp $W$ negative regulation in response to $\mathrm{H}_{2} \mathrm{O}_{2}$ and $\mathrm{HOCl}$. These results further expand our knowledge in both the mechanisms of ROS resistance and the role of $\mathrm{ArcAB}$ in this process.

\section{Results and discussion}

The OmpW porin facilitates $\mathrm{H}_{2} \mathrm{O}_{2}$ and $\mathrm{HOCl}$ diffusion through the $\mathrm{OM}$ and reconstituted proteoliposomes

Hydrogen peroxide and hypochlorous acid are ROS generated by phagocytic cells and in order to enter Gramnegative bacteria they must be able to cross the OM. Even though several biological membranes are permeable to $\mathrm{H}_{2} \mathrm{O}_{2}$, studies in E. coli and S. cerevisiae demonstrate that this compound cannot diffuse freely $[9,10]$. Additionally, the dielectric properties of $\mathrm{H}_{2} \mathrm{O}_{2}$ are comparable to those of water and this compound has a slighter larger dipolar moment, further limiting its diffusion through the $\mathrm{OM}$ lipid bilayer. For $\mathrm{HOCl}$, diffusion through the $\mathrm{OM}$ is also reported to be limited [11]. Therefore, $\mathrm{H}_{2} \mathrm{O}_{2}$ and $\mathrm{HOCl}$ must be channeled through the lipid bilayer and one possibility is the influx through porins. We recently demonstrated that the most abundant $\mathrm{OM}$ protein in $S$. Typhimurium, OmpD, allows $\mathrm{H}_{2} \mathrm{O}_{2}$ diffusion and is regulated by ArcAB [12]. Little is known about the diffusion of $\mathrm{HOCl}$, but genetic evidence has suggested that in E. coli porins might be used as entry channels for hypothiocyanate ions $\left(\mathrm{OSCN}^{-}\right)$, a molecule with a similar chemical structure generated by lactoperoxidase using thiocyanate and $\mathrm{H}_{2} \mathrm{O}_{2}$ as an oxidant [40]. In one study, ompC and ompF knockout mutants showed an increased resistance to $\mathrm{OSCN}^{-}$, however, a direct role of porins in mediating $\mathrm{HOCl}$ diffusion was not evaluated.

To assess whether OmpW allows the diffusion of $\mathrm{H}_{2} \mathrm{O}_{2}$ and $\mathrm{HOCl}$, scopoletin and dihydrorhodamine (DHR)-123 probes, respectively, were used to measure uptake of both toxic compounds separately in a wild type, $\triangle o m p W$ and a genetically complemented $\Delta o m p W(\mathrm{pBAD}-\mathrm{omp} W)$ strain as described in methods. The $\Delta o m p W$ strain showed an increase in extracellular fluorescence levels after exposure to $\mathrm{H}_{2} \mathrm{O}_{2}$ and $\mathrm{HOCl}$ resulting in higher extra/intracellular ratios (24 and 4-fold, respectively) as compared to the wild type strain, indicating that in the absence of OmpW the influx of both toxic compounds is decreased. Genetic complementation of $\Delta o m p W$ resulted in nearly identical 
levels of both extra and intracellular fluorescence as those observed in the wild type strain, suggesting that $\mathrm{OmpW}$ is necessary for $\mathrm{H}_{2} \mathrm{O}_{2}$ and $\mathrm{HOCl}$ uptake (Figure 1A and $\mathrm{C}$ ). Even though OmpW appears as a direct responsible for the influx of the compounds, a pleiotropic effect cannot be ruled out at this point because the absence of OmpW in the mutant strain could be producing a remodeling of the membrane organization.

To establish a direct contribution of OmpW in $\mathrm{H}_{2} \mathrm{O}_{2}$ and $\mathrm{HOCl}$ transport, we used reconstituted proteoliposomes. OmpW-proteoliposomes showed a decrease in $\mathrm{H}_{2} \mathrm{O}_{2}$ and $\mathrm{HOCl}$ extra/intraliposomal ratios (3.5 and 5-fold respectively) when compared to free liposomes (Figure $1 B$ and D). Proteoliposomes with $S$. Typhimurium OmpA porin were used as a negative control as previously described [12]. As expected, OmpA-proteoliposomes showed similar levels to those of free liposomes, indicating that $\mathrm{OmpW}$ facilitates $\mathrm{H}_{2} \mathrm{O}_{2}$ and $\mathrm{HOCl}$ uptake.

Since OmpW channels both toxic compounds across the lipid bilayer, we hypothesized that a $\Delta o m p W$ strain should be more resistant to both toxic compounds when compared to the wild type strain. As shown in Figure 2, exposure of $\Delta o m p W$ to $\mathrm{H}_{2} \mathrm{O}_{2} 4 \mathrm{mM}$ or $\mathrm{HOCl} 5 \mathrm{mM}$ resulted in an increase in the number of colony forming units (CFU) after $60 \mathrm{~min}$ of treatment. However, at longer periods the CFU count between strains $14028 \mathrm{~s}$ and $\Delta o m p W$ was similar. At $30 \mathrm{~min}$ post-treatment with either of the toxic compounds, strain $\Delta o m p W$ showed an increase from $1 \times 10^{6} \mathrm{CFU} / \mathrm{ml}$ to approximately $6 \times 10^{7}$ $\mathrm{CFU} / \mathrm{ml}$. In contrast, the $\mathrm{CFU} / \mathrm{ml}$ count for strain 14028 s remained almost unaltered at $1 \times 10^{6}$, resulting in a $1.5-\log _{10}$-fold increase in growth for $\Delta o m p W$. A similar result was observed after $60 \mathrm{~min}$ of treatment where the omp W mutant strain showed an increase from $6 \times 10^{7}$ to $1.5 \times 10^{9} \mathrm{CFU} / \mathrm{ml}$ while the wild type strain changed from $1 \times 10^{6}$ to $8 \times 10^{7} \mathrm{CFU} / \mathrm{ml}$. Our results suggest that the absence of OmpW in the mutant strain represents an advantage at short time points due to a decreased permeability towards both $\mathrm{H}_{2} \mathrm{O}_{2}$ and $\mathrm{HOCl}$. At longer periods, OM permeability should be reduced because exposure to both toxic compounds results in a negative regulation of $S$. Typhimurium porins including $\mathrm{OmpD}$, OmpC and OmpF [12,21]. One important possibility that cannot be ruled out at this time is that in the $\Delta o m p W$ strain, the expression of other porins or the OM lipid composition might be altered, therefore changing OM
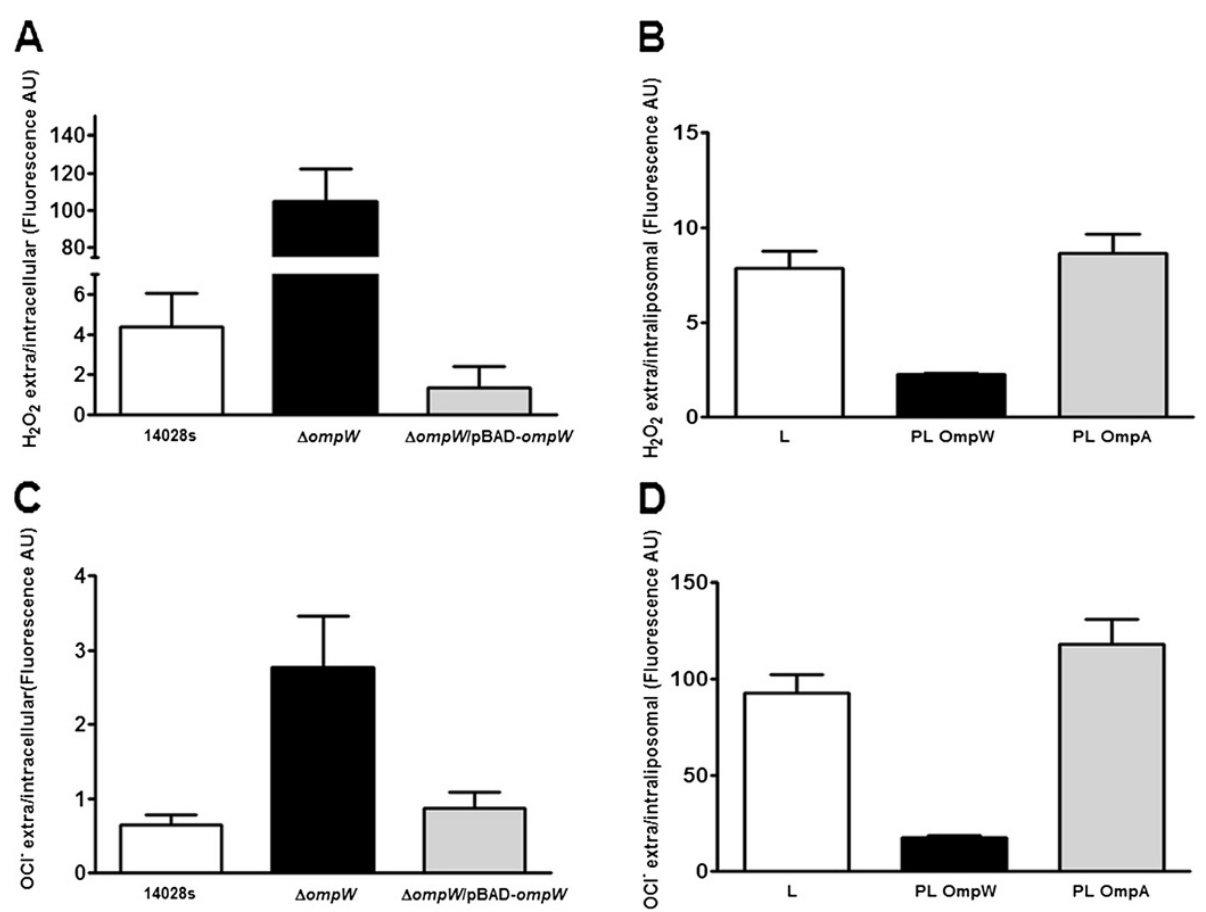

Figure $1 \mathrm{OmpW}$ facilitates $\mathrm{H}_{2} \mathrm{O}_{2}$ and $\mathrm{HOCl}$ diffusion through the outer membrane and reconstituted proteoliposomes. $\mathbf{A}$ and $\mathbf{C}$. $\mathrm{H}_{2} \mathrm{O}_{2}$ and $\mathrm{HOCl}$ levels were measured indirectly by specific fluorescence assays in the wild type (14028s), mutant ( $\triangle \mathrm{ompW}$ ) and genetically complemented strains ( $\triangle$ ompW/pBAD-ompW + arabinose). Exponentially growing cells were exposed to $\mathrm{H}_{2} \mathrm{O}_{2}$ (A) or $\mathrm{NaOCl}$ (C) for 5 min and fluorescence was determined in the extracellular (extra) and intracellular fractions. B and $\mathbf{D}$. Free liposomes (L), proteoliposomes reconstituted with S. Typhimurium OmpW (PL OmpW) or OmpA ( $\mathrm{PL} \mathrm{OmpA)} \mathrm{proteins} \mathrm{were} \mathrm{incubated} \mathrm{with} \mathrm{H}_{2} \mathrm{O}_{2}$ (B) or $\mathrm{NaOCl}$ (D) for 5 min and fluorescence was determined in the extraliposomal (extra) and intraliposomal fractions. AU indicates arbitrary units. Values represent the average of four independent experiments \pm SD. 


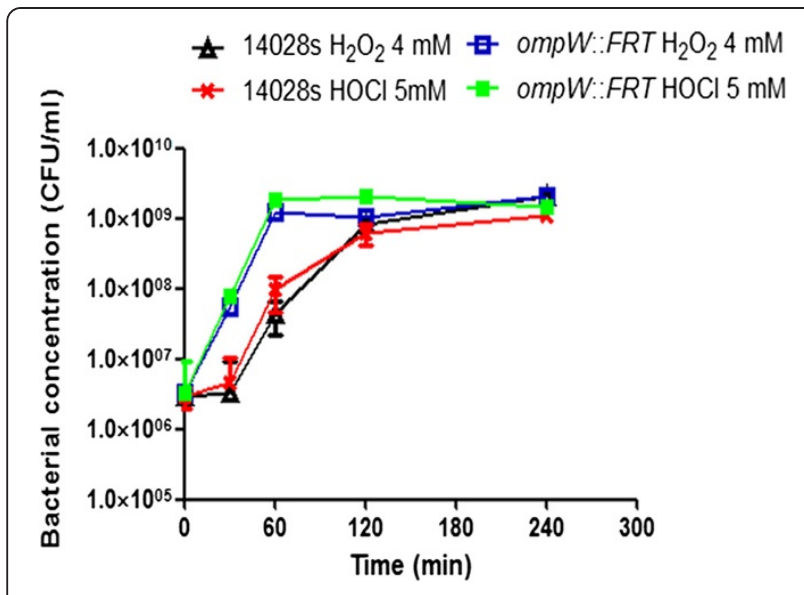

Figure 2 Bacterial concentration of $S$. Typhimurium 14028s and $\Delta$ ompW exposed to $\mathrm{H}_{2} \mathrm{O}_{2}$ or $\mathrm{NaOCl}$. Cultures of $14028 \mathrm{~s}$ and $\triangle$ ompW were grown to $\mathrm{OD} \sim 0.4$ and treated with $\mathrm{H}_{2} \mathrm{O}_{2} 4 \mathrm{mM}$ or $\mathrm{NaOCl} 5 \mathrm{mM}$ in LB medium. Time of treatment is indicated. Bacterial concentrations were determined by plating. The values are the concentrations of surviving bacteria after exposure to $\mathrm{H}_{2} \mathrm{O}_{2}$ or $\mathrm{NaOCl}$. Experiments were performed in triplicate. Error bars indicate SD.

permeability. For example, a study conducted in $E$. coli showed that an ompC knockout mutant had increased levels of OmpA [40], however, changes in permeability were not evaluated. Furthermore, this has not been evaluated in a $S$. Typhimurium or E. coli $\Delta o m p W$ strain.

Our data supports the proposed model where OmpW allows the influx of small polar molecules, like $\mathrm{H}_{2} \mathrm{O}_{2}$ and $\mathrm{HOCl}$. The crystal structure of OmpW from E. coli revealed that the cross-section of the barrel has approximate dimensions of $17 \times 12 \AA$ along the length of the barrel and although the interior of the channel has a hydrophobic character, the observed single channel activities shows that polar molecules traverse the barrel [17]. Taken together, these results provide biochemical and genetic evidence indicating that both toxic compounds are channeled through OmpW. From our knowledge, this is the first direct evidence of $\mathrm{HOCl}$ diffusion through porins. Furthermore, preliminary analyses indicate that $\mathrm{H}_{2} \mathrm{O}_{2}$ and $\mathrm{HOCl}$ channeling is common for $S$. Typhimurium OmpD, OmpC and OmpF porins (unpublished data).

\section{Hydrogen peroxide and hypochlorous acid exposure results in ompW negative regulation}

Since the OmpW porin channels $\mathrm{H}_{2} \mathrm{O}_{2}$ and $\mathrm{HOCl}$ through the $\mathrm{OM}$ and exposure to these molecules is detrimental to bacteria, we hypothesized that $0 m p W$ should be negatively regulated when $S$. Typhimurium is exposed to $\mathrm{H}_{2} \mathrm{O}_{2}$ and $\mathrm{HOCl}$. To study this effect, wild type $S$. Typhimurium cells were grown to mid-log phase, exposed to $\mathrm{H}_{2} \mathrm{O}_{2}$ or $\mathrm{HOCl}$ and $o m p W$ mRNA levels were measured by qRT-PCR. As seen in Figure 3, exposure to $\mathrm{H}_{2} \mathrm{O}_{2}$ and $\mathrm{HOCl}$ resulted in lower levels of $\mathrm{omp} W$ transcripts $(0.27 \pm 0.04$ and $0.156 \pm$ 0.079 , respectively) relative to control untreated cells. In agreement with our results of omp $W$ negative regulation, similar results were observed by Wang et al. (2010) who showed that $S$. Enteritidis and Typhimurium cells exposed to $\mathrm{HOCl}$ results in modulation of ompD, ompC, ompF (negatively) and ompA (positively) expression. Furthermore, Calderón et al. (2011) demonstrated that the $S$. Typhimurium ompD gene is negatively regulated in response to $\mathrm{H}_{2} \mathrm{O}_{2}$. Therefore, our and all the published data suggest that in the presence of $\mathrm{OCl}^{-}$or $\mathrm{H}_{2} \mathrm{O}_{2}$ there might be a general lowering in the concentration of porins in the outer membrane, in order to diminish the permeability. To assess the specificity of our assay, we evaluated ompD, $o m p C$ and $\operatorname{arcB}$ transcript levels as positive (ompD and ompC) and negative controls $(\operatorname{arc} B)$. The $\operatorname{arc} B$ gene was used as a negative control based on our microarray analysis which shows that it remains unaltered under these conditions and between strains 1408s and $\triangle \operatorname{arc} A$ (unpublished data). Our results indicate that after exposure to both toxic compounds, $\operatorname{arcB}$ transcript levels remain unchanged while those of $о m p D$ and $о m p C$ are lowered as compared to untreated cells (Figure 3). Therefore, all the evidence indicates that $\mathrm{OM}$ permeability is tightly regulated in response to ROS and could represent a novel mechanism of resistance when bacteria are exposed to these toxic compounds.

\section{ArcA binds the ompW promoter region}

In addition to the soxRS and oxyR systems, several studies have provided evidence that the ArcAB two component system plays an important role in the resistance to

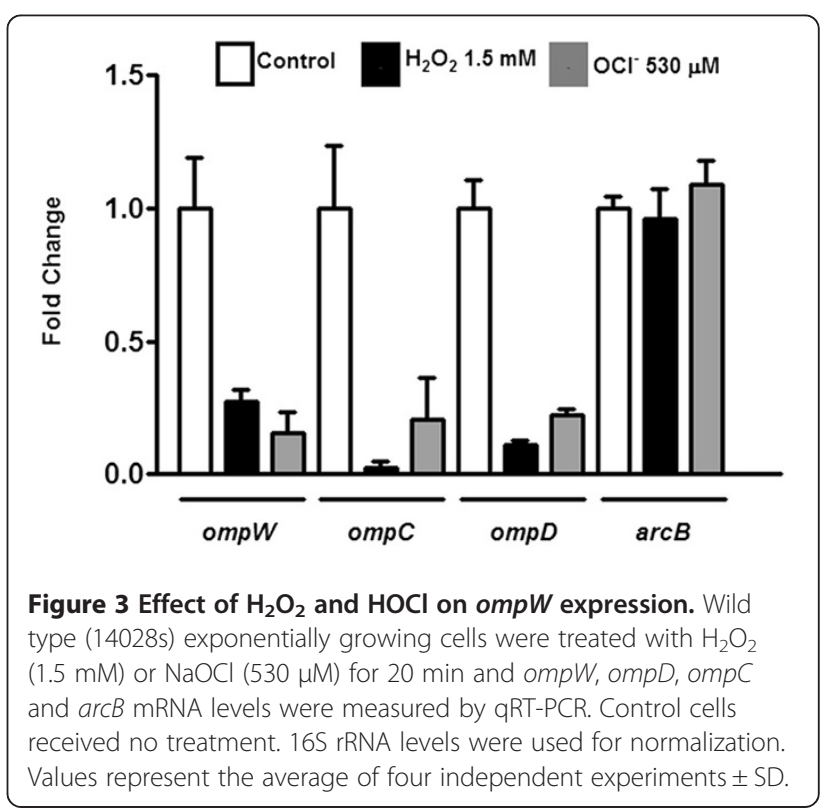


ROS induced damage. For example, ArcA is essential for $S$. Enteritidis and Typhimurium resistance to ROS [24,27] and E. coli mutant strains of the sensor ArcB and the regulator ArcA, show an increased susceptibility to $\mathrm{H}_{2} \mathrm{O}_{2}$ [26]. However, neither of these studies identified genes directly regulated by the system under oxidative stress. We recently demonstrated that ArcA negatively regulates the expression of $S$. Typhimurium ompD after $\mathrm{H}_{2} \mathrm{O}_{2}$ exposure by direct interaction with its promoter region [12]. To determine if ArcA mediates ompW down-regulation in response to $\mathrm{H}_{2} \mathrm{O}_{2}$ and $\mathrm{HOCl}$, a search for putative ArcA binding sites at the ompW promoter region was performed using Virtual Footprint 3.0 [41]. The analysis predicted the presence of three ArcA binding sites (ABS) located at positions -61 to -70 (ABS-1, forward orientation), -230 to -239 (ABS-2) and -286 to -295 (ABS-3, both in reverse orientation) relative to the experimentally determined transcription start site [42]. Comparison with the extended core region $5^{\prime}$ GTTAATTAAATGTTA-3' described by Evans et al. (2011) further revealed that only ABS-1 presented a high degree of identity (14 out of 15 nucleotides) with the consensus sequence. To confirm or rule out a direct interaction between ArcA and the predicted binding sites, deletions of the promoter region were generated by PCR (schematized in Figure 4B) and used to perform non-radioactive EMSAs with ArcA and phosphorylated
ArcA (ArcA-P). The purity of the protein was assessed by PAGE and ArcA was the dominant product. Electrophoretic mobility shift with ArcA-P was only observed when incubated with fragments that included ABS-1 (Figure 4C and D, W1 and W4). No shifts were observed in fragments that include both ABS-2 and ABS-3 (W3, even at threefold excess) or control fragments that did not include any ABS (W2 and W5). Non-phosphorylated ArcA only generated electrophoretic mobility shifts at higher concentrations (over $1200 \mathrm{nM}$ ) where the negative controls were also retarded as a result of non-specific binding (Figure 3E). Taken together our bioinformatic and EMSA analyses indicate that ArcA-P binds to the ompW promoter region at a site located between positions -80 and -41 and suggests that this site is ABS-1 which is located between positions -70 to -55 .

\section{Evaluating ArcA binding site 1 (ABS-1) functionality}

To further confirm that ABS-1 (Figure 4A) was the functional ArcA binding site mediating omp $W$ negative regulation in response to ROS, we constructed transcriptional fusions of the ompW promoter region. We generated two different fusions which included the whole promoter from positions +1 to -600 , with respect to the translation start site. One construction contained the native promoter (pompW-lacZ) while substitutions that mutated ABS-1 (shown in red and underlined,
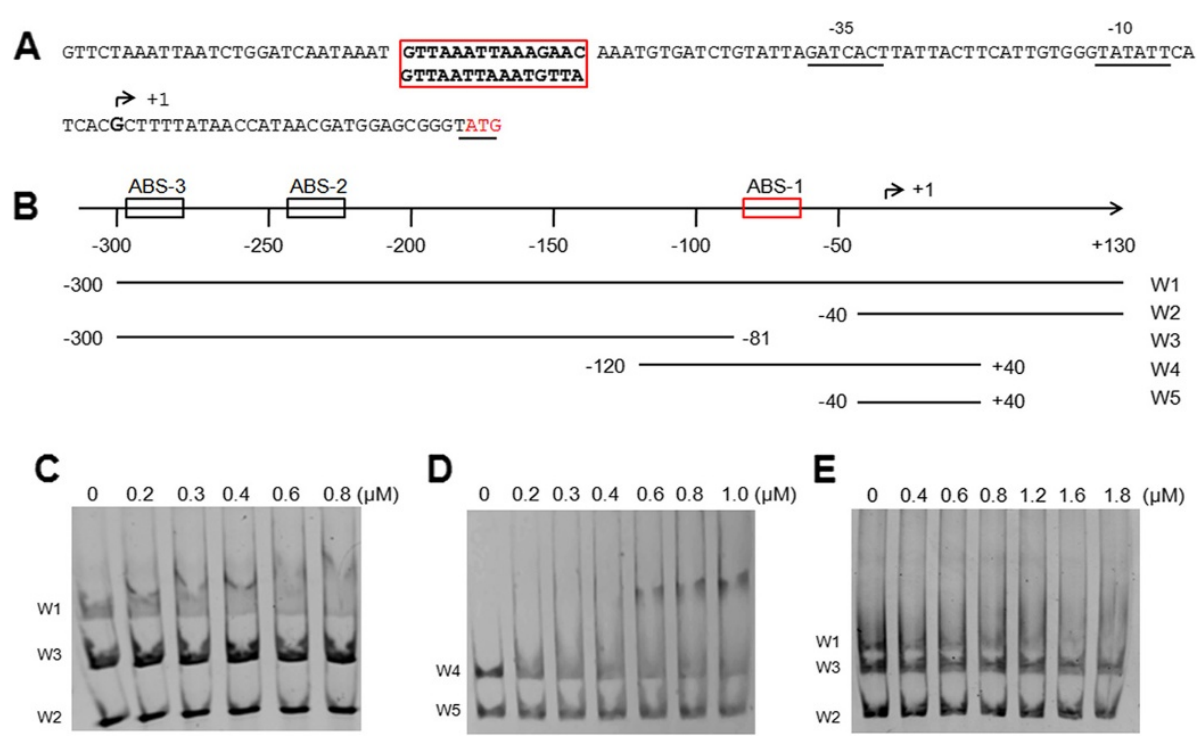

D

E
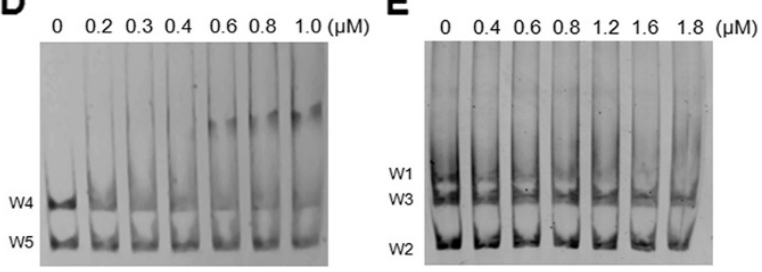

Figure 4 ArcA binding to the ompW promoter region. A. S. Typhimurium ompW promoter region. Black and red boxes indicate predicted ArcA binding sites. -10 and -35 boxes are underlined. The transcription start site is shown in bold and indicated as +1 . The translation start site is underlined and in red. The consensus ArcA binding site is shown under the promoter sequence. B. Schematic representation of the ompW promoter region. Positions relative to the transcription start site are indicated. ArcA binding sites are indicated as in the text. PCR products used in EMSAs are shown and names of each fragment are indicated. C,D and E. EMSA of the ompW promoter region. A 3-fold excess (60 ng) of fragments W2 and W3 were incubated with W1 (C) and the fragment W4 was incubated with W5 (D) and increasing amounts of phosphorylated ArcA as indicated on the top of each gel. (E) W1, W2 and W3 were incubated with increasing amounts of non-phosphorylated ArcA. 
Figure 5A) were included in the second construction (pompW/ABS1-lacZ). The constructions were transformed into the wild type strain and $\beta$-galactosidase activity was measured in response to treatment with $\mathrm{H}_{2} \mathrm{O}_{2}$ and $\mathrm{HOCl}$.

The activity of the constructions was compared to the untreated 14028 s strain with the wild type fusion. Treatment of this strain with $\mathrm{H}_{2} \mathrm{O}_{2}$ and $\mathrm{HOCl}$ resulted in lower activity levels $(0.58 \pm 0.008$ and $0.53 \pm 0.095$, respectively), in agreement with qRT-PCR experiments. However, a 5 nucleotide substitution of the most conserved residues at $\mathrm{ABS}-1$ site (pompW/ABS1-lacZ) resulted in no regulation after exposure to either of the toxic compounds $(1,09 \pm 0.104$ and $0,93 \pm 0.061)$, indicating that they are relevant for the transcriptional activity of ompW in response to $\mathrm{H}_{2} \mathrm{O}_{2}$ and $\mathrm{HOCl}$ (Figure 5B). Furthermore, these results are in agreement with EMSAs which indicate that ArcA only binds to fragments containing ABS-1.

\section{The ArcAB two component system mediates ompW negative regulation}

To establish a direct relationship between omp $W$ negative regulation and ArcA-P binding to its promoter region, omp $W$ expression was evaluated by qRT-PCR in a $\triangle \operatorname{arcA}$ strain exposed to $\mathrm{H}_{2} \mathrm{O}_{2}$ and $\mathrm{HOCl}$. The negative regulation observed in the wild type strain was not retained in an $\operatorname{arc} A$ mutant treated with either of the toxic compounds and omp $W$ transcript levels were similar as those observed in untreated cells. Genetic complementation of $\triangle \operatorname{arc} A$ restored the negative regulation observed in wild type cells exhibiting lower ompW mRNA levels $(0.161 \pm 0.068$ and $0.488 \pm 0.027$, respectively) as compared to untreated cells (Figure 6A and C). Growth of the genetically complemented strain in the presence of glucose (non-induction) resulted in similar omp $W$ mRNA levels between treated and untreated cells (data not shown). As controls, we measured ompD, ompC and $\operatorname{arcB}$ transcript levels after exposure to $\mathrm{H}_{2} \mathrm{O}_{2}$ and $\mathrm{HOCl}$ in a $\triangle \operatorname{arcA}$ strain. Transcript levels of ompD were measured since its expression is regulated by ArcA under ROS conditions [12]. Our results indicate that neither $\operatorname{ompD}$ or $\operatorname{arcB}$ transcript levels were decreased after exposure to $\mathrm{H}_{2} \mathrm{O}_{2}$ or $\mathrm{HOCl}$ while those of ompC remained regulated in a $\triangle \operatorname{arc} A$ strain treated with either of the toxic compounds (Figure 6A), confirming that ArcA mediates $o m p D$ regulation under ROS conditions and showing that the expression of $\operatorname{ompC}$ is ArcA independent and regulated by different mechanisms which remain unsolved to the date, and are under study in our laboratory. Furthermore, our bioinformatic analyses in search for ArcA motifs predicted binding sites in the promoter regions of $o m p W$ and $o m p D$, but not for $o m p C$ ([12], data not shown).

To determine whether the negative regulation by ArcA was dependant on its cognate sensor ArcB, ompW

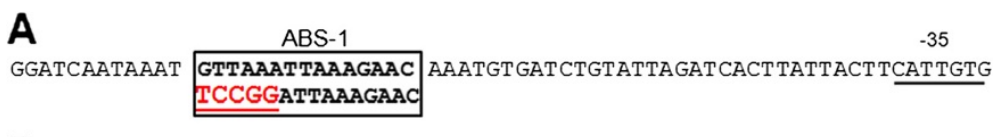

B

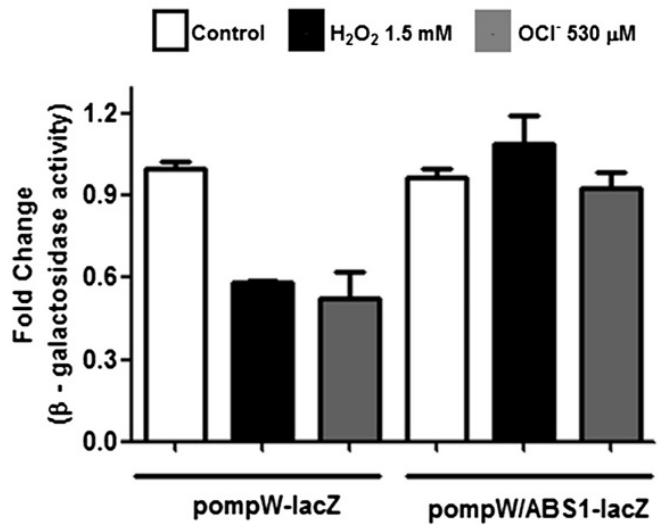

Figure 5 Evaluating ArcA binding site 1 (ABS-1) functionality at the ompW promoter. (A) Schematic representation of substitutions generated at the $\mathrm{ompW}$ promoter. Substituted bases are in red, underlined and shown below the core ArcA binding sequence. Black box indicates ABS-1. -35 is indicated. (B) Expression of the wild type and mutagenized regulatory region of ompW in S. Typhimurium. Strain 14028s was transformed with the reporter plasmids pompW-lacZ (wild type) or pompW/ABS1-lacZ (ABS-1 mutated). Cells were grown to OD $\sim 0.4$ and treated with $\mathrm{H}_{2} \mathrm{O}_{2} 1.5 \mathrm{mM}$ or $\mathrm{NaOCl} 530 \mu \mathrm{M}$ for $20 \mathrm{~min}$ and $\beta$-galactosidase activity was measured. Values represent the average of three independent experiments \pm SD. 


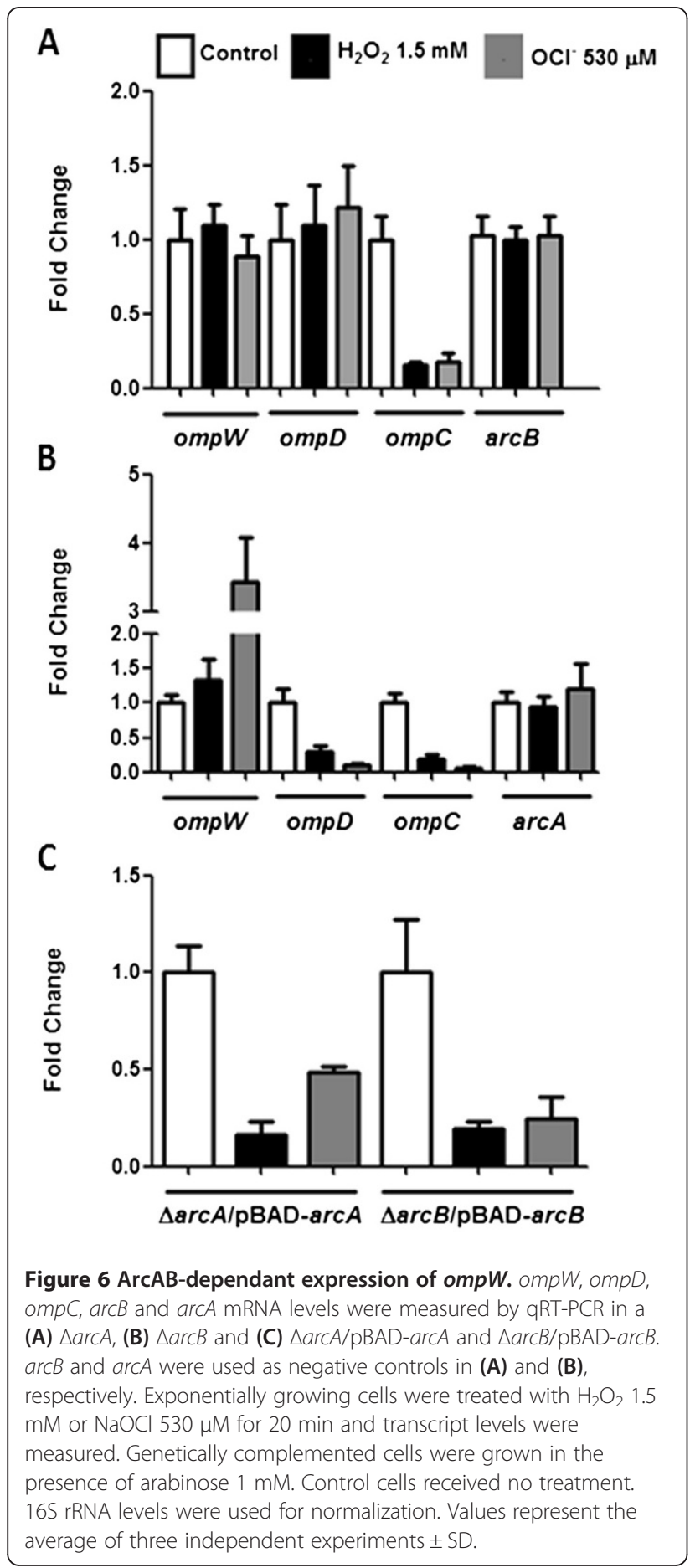

mRNA levels were evaluated in a $\triangle a r c B$ strain. In contrast to the negative regulation observed in wild type cells, omp $W$ mRNA levels were further increased in a $\triangle \operatorname{arcB}$ strain after exposure to $\mathrm{HOCl}(3.37 \pm 1.09)$. Transcript levels after treatment with $\mathrm{H}_{2} \mathrm{O}_{2}$ were similar as those observed in untreated cells (Figure 6B). One possibility for this result is that in the absence of ArcA, ArcB might phosphorylate (i.e ArcB-OmpR, [43]) one or more response regulators, either unspecifically or due to crosstalk, which could bind to the promoter region and therefore prevent binding of positive regulators like SoxS, which has been demonstrated to regulate $o m p W$ and is up-regulated in response to $\mathrm{HOCl}[20,44]$. This could result in constant ompW transcript levels as shown in Figure 6A. On the other hand, in the absence of ArcB no phosphorylation occurs and SoxS or other positive regulator(s) might have free accessibility to the $o m p W$ promoter and therefore increase its expression (Figure 6B), although this possibility has not been evaluated in this study. Genetic complementation of $\triangle \operatorname{arcB}$ restored the negative regulation observed in wild type cells exposed to $\mathrm{H}_{2} \mathrm{O}_{2}$ and $\mathrm{HOCl}(0.19 \pm 0.04$ and $0.24 \pm 0.11$, respectively, Figure 6C). The $o m p D$ and $о m p C$ transcripts levels remained down-regulated after exposure to $\mathrm{H}_{2} \mathrm{O}_{2}$ and $\mathrm{HOCl}$ in the $\triangle \operatorname{arcB}$ strain, while the negative control $\operatorname{arcA}$ remained unaltered (Figure 6B).

The ArcA regulon in anaerobically grown $S$. Typhimurium was recently determined [27]. Interestingly, neither ompD nor omp $W$ expression was down-regulated in an ArcA dependant manner, suggesting that the ArcA regulon under anaerobic and aerobic ROS conditions could be different. Even in E. coli, omp $W$ expression is suggested to be regulated by FNR in response to oxygen availability [39]. The difference between the ArcA regulons under aerobic and ROS conditions might be explained by studies suggesting that the mechanism of ArcA activation under aerobic conditions is different from those classically described. E. coli mutant strains in residue $\mathrm{H}-717$ of ArcB are able to phosphorylate and activate ArcA through the transfer of the phosphate group from residue His-292 under aerobic conditions [45] and Loui et al. (2009) suggested that $\mathrm{H}_{2} \mathrm{O}_{2}$ resistance is independent of ArcA phosphorylation at residue Asp-54. To the date, the detailed molecular mechanism of ArcAB activation in response to ROS remains unsolved. Therefore, further experiments to unveil the molecular mechanism by which the $S$. Typhimurium ArcAB two component system is activated are needed and under way in our laboratory.

\section{Conclusion}

We provide both genetic and biochemical evidence indicating that the OM porin OmpW mediates the influx of $\mathrm{H}_{2} \mathrm{O}_{2}$ and $\mathrm{HOCl}$. The results revealed that the $S$. Typhimurium omp $W$ gene is negatively regulated upon exposure to both toxic compounds. Furthermore, we demonstrate that the response regulator ArcA mediates omp $W$ negative regulation in response to $\mathrm{H}_{2} \mathrm{O}_{2}$ and $\mathrm{HOCl}$ via a direct interaction with the upstream region of ompW. Taken together, with our previous observation that $\mathrm{OmpD}$ mediates influx of $\mathrm{H}_{2} \mathrm{O}_{2}$ and is negatively regulated by ArcA in response 
to $\mathrm{H}_{2} \mathrm{O}_{2}$, these results further expand our knowledge regarding the coordinated regulatory mechanisms of ROS resistance and the role of ArcAB in this process.

\section{Methods}

\section{Bacterial strains and growth conditions}

Bacterial strains used in this work are listed in Table 1. Cells were grown aerobically with agitation in LB medium at $37^{\circ} \mathrm{C}$. Solid media consisted of agar $\left(20 \mathrm{~g} \mathrm{l}^{-1}\right)$ and plates were incubated at $37^{\circ} \mathrm{C}$. Dilutions (1:100) of overnight cultures were used to initiate growth. When necessary, growth media was supplemented with the appropriate antibiotics (see below).

\section{Strain construction and genetic complementation}

$S$. Typhimurium $\operatorname{arcB}$ gene was interrupted by gene disruption as previously described [46]. Strain 14028s (wild type) harboring plasmid pKD46 was grown in the presence of arabinose $(10 \mathrm{mM})$ and ampicillin $\left(100 \mu \mathrm{g} \mathrm{ml}^{-1}\right)$ to $\mathrm{OD}_{600} \sim 0.4$, made electrocompetent and transformed with a PCR product generated with plasmid $\mathrm{pKD} 3$ as template and primers $5^{\prime}$ ATTGGGTATTATGTGCGAAGTTGTGGTGAAGGAATCCTCTTGTAGGCTGGA
GCTGCTTCG 3' (WarcBF) and 5' GGTGTTGGCGCAGTATTCGCGCACCCCGGTCAAACCGGGGCATATGAATATCCTCCTTAG 3' (WarcBR). Transformants were selected on LB plates supplemented with chloramphenicol $\left(20 \mu \mathrm{g} \mathrm{ml}^{-1}\right)$ and confirmed by PCR using primers 5' GCTACGCATATTTCGCACAA 3' (arcBF) and 5' GCGCCTTTGACATCATCATA 3' (arcBR).

Genetic complementation of the $\triangle a r c B$ strain was performed using plasmid pBAD- $\operatorname{arcB}$. To generate this plasmid, $S$. Typhimurium $\operatorname{arcB}$ gene was amplified by PCR using primers 5' ATGAAGCAAATTCGTATGCTG 3' (pBADarcBF) and 5' TCATTTTTTTTCCGCGTTTGCCACCC 3' (pBADarcBR) and cloned into plasmid pBAD$\mathrm{TOPO} \mathrm{TA}^{\bullet}$ (Invitrogen) according to manufacturer's instructions. Insertion was verified by DNA sequencing.

\section{Bacterial survival after exposure to oxidative stress}

Bacteria were cultured in $5 \mathrm{ml}$ of $\mathrm{LB}$ medium at $37^{\circ} \mathrm{C}$ overnight with shaking. Antibiotics were added as appropriate. 1:1000 dilutions of the overnight cultures were grown in $25 \mathrm{ml}$ to $\mathrm{OD} \sim 0.4$ and $\mathrm{H}_{2} \mathrm{O}_{2} 4 \mathrm{mM}$ or $\mathrm{NaOCl}$ $5 \mathrm{mM}$ (final concentration) were added. In all the assays the cultures were grown aerobically at $250 \mathrm{rpm}$. Aliquots

Table 1 Bacterial strains used in this study

\begin{tabular}{|c|c|c|}
\hline Strain & Relevant characteristic(s) & Source \\
\hline \multicolumn{3}{|l|}{ S. Typhimurium } \\
\hline $14028 s$ & wild type strain & G. Mora \\
\hline 14028s/pompW-lacZ & $\begin{array}{l}\text { 14028s transformed with a derivative of plasmid } \\
\text { pLacZ-Basic carrying the ompW promoter } \\
\text { (nt }-600 \text { to }+1 \text { ) }\end{array}$ & This work \\
\hline 14028s/pompW/ABS1-lacZ & $\begin{array}{l}\text { 14028s transformed with a derivative of plasmid } \\
\text { pLacZ-Basic carrying the ompW promoter } \\
\text { (nt }-600 \text { to }+1 \text { ) with substitution GTTAA to TCCGG } \\
\text { into position }-70 \text { to }-66\end{array}$ & This work \\
\hline$\Delta o m p W$ & ompW::kan & C. Saavedra \\
\hline$\Delta o m p W / p B A D-o m p W$ & $\begin{array}{l}\triangle o m p W \text { strain complemented with pBAD vector } \\
\text { carrying the } S \text {. Typhimurium ompW gene }\end{array}$ & C. Saavedra \\
\hline$\triangle \operatorname{arcA}$ & $\operatorname{arcA::cam~}$ & {$[12]$} \\
\hline$\triangle \operatorname{arcA}$ pBAD-arcA & $\begin{array}{l}\triangle \text { arcA strain complemented with pBAD vector } \\
\text { carrying the } S \text {. Typhimurium arcA gene }\end{array}$ & {$[12]$} \\
\hline$\triangle \operatorname{arcB}$ & $\operatorname{arcB::cam}$ & This work \\
\hline$\triangle \operatorname{arcB} / \mathrm{pBAD}-\operatorname{arcB}$ & $\begin{array}{l}\triangle \operatorname{arcB} \text { strain complemented with pBAD vector } \\
\text { carrying the } S \text {. Typhimurium } \operatorname{arcB} \text { gene }\end{array}$ & This work \\
\hline E. coliTop10 & $\begin{array}{l}\text { F- } m c r A \Delta(\text { mrr-hsdRMS-mcrBC) } \text { (180lacZ } \Delta \text { M15 } \\
\Delta \text { lacX74 recA1 araD139 } \Delta \text { (ara-leu)7697 galU } \\
\text { galK rpsL (StrR) endA1 nupG }\end{array}$ & Invitrogen \\
\hline Top10 pBAD-ompW & $\begin{array}{l}\text { Top10 transformed with the pBAD vector carrying } \\
\text { the } S . \text { Typhimurium ompW gene }\end{array}$ & C. Saavedra \\
\hline Top10 pBAD-ompA & $\begin{array}{l}\text { Top10 transformed with the pBAD vector carrying } \\
\text { the S. Typhimurium ompA gene }\end{array}$ & C. Saavedra \\
\hline Top10 pBAD-arcB & $\begin{array}{l}\text { Top10 transformed with the pBAD vector carrying } \\
\text { the } S \text {. Typhimurium arcB gene }\end{array}$ & This work \\
\hline BL21 pET-TOPOArcA & $\begin{array}{l}\text { BL21(DE3) transformed with the pET-TOPO101ArcA } \\
\text { vector carrying the S. Typhimurium arcA gene }\end{array}$ & {$[12]$} \\
\hline
\end{tabular}


of cultures were withdrawn at the different time points, diluted and plated in triplicate. Bacterial cultures were enumerated by counting the number of CFU after overnight incubation to determine the bacterial concentrations.

\section{Construction of transcriptional fusions with reporter gene lacZ}

The native $o m p W$ promoter region from positions +1 to -600 (with respect to the translation start) site was amplified by PCR with primers ompW_PLacZ_-600F_ATG 5' CGGGGTACCCCCGATATCGAAAATTCGCG $3^{\prime}$ and ompW_pLacZ_-1R_ATG 5' CCCAAGCTTACCCGCTCCATCGTTATGGT 3' using genomic DNA from $S$. Typhimurium (strain 14028s). The restriction sites (KpnI and HindIII, respectively) at the ends of the DNA fragment were introduced by the PCR primers (underlined sequences) and digested with the corresponding enzymes. The digested PCR product was cloned into the multiple cloning site (MCS) of the $\beta$-galactosidase reporter vector pLacZ-Basic (GenBank accession no. U13184), Clontech, generating plasmid pompW-lacZ. To generate plasmid pompW/ABS1-lacZ, primers ompW_pLacZ_-600F_ATG with Mut_sit_arcAR 5' TGTTCTTATAATGCGGAATTTATTGATCCAG 3' and ompW_pLacZ_-1R_ATG with Mut_sit_arcAF 5' CTGGATCAATAAATTCCGGAATTATAAGAACA 3' were used to generate overlapping PCR products spanning the whole length of the ompW promoter. Mutation of ABS-1 was generated by incorporating substitutions in primers Mut_sit_arcAF and Mut_sit_arcAR (underlined sequences). The resulting PCR products were used as templates in a second reaction with primers ompW_pLacZ_-600F_ATG and ompW_pLacZ_-1R_ATG to generate the mutated ompW promoter, which was digested and cloned into the MCS of plasmid pLacZ-Basic. Constructions were confirmed by DNA sequencing. The generated constructs were transformed into wild type strain 14028s. To evaluate activity, cells at $\mathrm{OD}_{600} \sim 0.4$ were grown for 20 min in the presence of $\mathrm{H}_{2} \mathrm{O}_{2}(1.5 \mathrm{mM})$ or $\mathrm{NaOCl}$ (530 $\mu \mathrm{M})$. Control cells received no treatment. $\beta$-galactosidase activity was determined as previously described [20].

\section{Protein purification}

His-tagged ArcA used in EMSAs was purified as previously described [12]. Briefly E. coli BL21 cells harboring plasmid pET-TOPO-arcA were grown in $500 \mathrm{ml}$ of LB medium supplemented with amplicillin $\left(100 \mu \mathrm{g} \mathrm{ml}^{-1}\right)$ to $\mathrm{OD}_{600} \sim 0.4$ and protein overexpression was carried out by adding $1 \mathrm{mM}$ IPTG and further growth for $6 \mathrm{~h}$. Protein was purified by affinity chromatography as described by Georgellis et al., (1997).

Outer membrane proteins used in proteoliposomes were purified as described by Calderón et al. (2011). E. coli Top10 cells carrying pBAD-ompA or pBAD-omp $W$ were grown in $500 \mathrm{ml}$ to $\mathrm{OD}_{600} \sim 0.6$ at $37^{\circ} \mathrm{C}$ and overexpression was performed for $5 \mathrm{~h}$ in the presence of $1 \mathrm{mM}$ arabinose. His-tagged porins were purified by affinity chromatography using HisTrap HP columns (Amersham) according to the manufacturer's instructions.

Plasmid pBAD-omp $W$ was generated amplifying the coding region of $S$. Typhimurium omp $W$ by PCR using primers 5' ATGAAAAAATTTACAGTGGC 3' (pBADompWF) and 5' GAAACGATAGCCTGCCGAG 3' (pBAD-ompWR) and cloned into plasmid pBAD-TOPO $\mathrm{TA}^{\circ}$ (Invitrogen) according to the manufacturer's instructions. Insertion was verified by DNA sequencing.

\section{RNA isolation and ompW mRNA detection}

Overnight cultures were diluted (1:100) and cells were grown to $\mathrm{OD}_{600} \sim 0.4$. Genetically complemented cells $(\triangle \operatorname{arc} A / \mathrm{pBAD}-\operatorname{arc} A$ and $\triangle \operatorname{arcB} / \mathrm{pBAD}-\operatorname{arcB})$ were grown in the presence of arabinose $(1 \mathrm{mM})$ and ampicillin (100 $\left.\mu \mathrm{g} \mathrm{ml}^{-1}\right)$. At this point, $\mathrm{H}_{2} \mathrm{O}_{2}(1.5 \mathrm{mM})$ or $\mathrm{NaOCl}(530$ $\mu \mathrm{M})$ was added and cells were grown for $20 \mathrm{~min}$. Control cells received no treatment. After exposure to the toxic compounds, $4 \mathrm{ml}$ were withdrawn from the culture and used to extract total RNA using GenElute Total RNA purification $\mathrm{Kit}^{\circ}$ (Sigma). Total RNA treatment with DNase I and cDNA synthesis was performed as previously described [19].

Relative quantification of $o m p W$ mRNA was performed using Brilliant II SYBR Green QPCR Master Reagent Kit and the Mx3000P detection system (Stratagene). 16S rRNA was used for normalization. Specific primers were 5' ATGAAAAAATTTACAGTGG 3' (RTompWF) and 5' GAAACGATAGCCTGCCGA 3' (RTompWR) for the omp $W$ gene; 5' GTAGAATTCCAGGTGTAGCG 3' (16SF) and 5' TTATCACTGGCAGTCTCCTT 3' (16SR) for $16 \mathrm{~S}$ rRNA gene (16S). The reaction mixture was carried out in a final volume of $20 \mu \mathrm{l}$ containing $1 \mu \mathrm{l}$ of diluted cDNA (1:1000), $0.24 \mu \mathrm{l}$ of each primer $(120 \mathrm{nM})$, $10 \mu \mathrm{l}$ of $10 \mathrm{x}$ Master Mix, $0.14 \mu \mathrm{l}$ of diluted ROX (1:200) and $8.38 \mu \mathrm{l}$ of $\mathrm{H}_{2} \mathrm{O}$. The reaction was performed under the following conditions: $10 \mathrm{~min}$ at $95^{\circ} \mathrm{C}$ followed by 40 cycles of $30 \mathrm{~s}$ at $95^{\circ} \mathrm{C}, 30 \mathrm{~s}$ at $53^{\circ} \mathrm{C}$ and $45 \mathrm{~s}$ at $72^{\circ} \mathrm{C}$. Finally a melting cycle from 53 to $95^{\circ} \mathrm{C}$ was performed to check for amplification specificity. Amplification efficiency was calculated from a standard curve constructed by amplifying serial dilutions of RT-PCR products for each gene. These values were used to obtain the fold change in expression for the gene of interest normalized with $16 \mathrm{~S}$ levels according to [47]. Experiments were performed in three biological and technical replicates.

\section{DNA binding assays}

Non-radioactive EMSAs were performed as described [48]. Briefly, increasing amounts of purified ArcA (phosphorylated and unphosphorylated) were incubated 
with 20 or 60 ng of PCR product(s) in binding buffer (100 $\mathrm{mM}$ Tris-Cl [pH 7.4], $100 \mathrm{mM} \mathrm{KCl,} 10 \mathrm{mM} \mathrm{MgCl}_{2}, 10 \%$ glycerol, and $2 \mathrm{mM}$ dithiothreitol) for $20 \mathrm{~min}$ at $30^{\circ} \mathrm{C}$. Reaction mixtures were immediately loaded on prerun $4 \%$ native polyacrylamide gels. The DNA-protein complexes were visualized by ethidium bromide staining. PCR fragments used in EMSAs were generated by PCR using reverse primer 5' ACCCGCTCCATCGTTATGGT 3' (ompWR) in combination with 5' GAGCAGACAAATATTTGCAT 3' (300WF) or 5' TATTAGATCACTTATTACTT 3' (170WF) to generate fragments W1 and W2, respectively. Fragment W3 was generated using primers 300WF and 5' GATCCAGATTAATTTAGAAC $3^{\prime}$. Fragments W4 and W5 were generated by using reverse primer $5^{\prime}$ AATTTTTTCATACCCGCTCC 3' in combination with primers $5^{\prime}$ CCTATAACCAGGATTTTCAA 3' and 170WF, respectively. ArcA phosphorylation was carried out as described by Linch and Lin (1996). Briefly purified ArcA was incubated with $50 \mathrm{mM}$ disodium carbamoyl phosphate (Sigma) in a buffer containing $100 \mathrm{mM}$ Tris-Cl (pH 7.4), $10 \mathrm{mM} \mathrm{MgCl}, 125 \mathrm{mM} \mathrm{KCl}$, for $1 \mathrm{~h}$ at $30^{\circ} \mathrm{C}$ and used immediately in EMSA assays.

\section{In vivo and in vitro determination of hydrogen peroxide and hypochlorous acid diffusion}

In vivo diffusion of $\mathrm{H}_{2} \mathrm{O}_{2}$ was assessed as previously described [12]. For $\mathrm{HOCl}$ detection, overnight cultures were diluted and cells were grown to $\mathrm{OD}_{600} \sim 0.5$. Two $\mathrm{ml}$ of bacterial culture were centrifuged for $5 \mathrm{~min}$ at $4500 \mathrm{xg}$ and resuspended in $1 \mathrm{ml}$ of $100 \mathrm{mM}$ phosphate buffer $(\mathrm{pH}$ 7.2). A $200 \mu \mathrm{l}$ aliquot was incubated for 5 min with 530 $\mu \mathrm{M} \mathrm{NaOCl}$ and constant agitation. Following, cells were vacuum filtered using polycarbonate filters of $0.025 \mu \mathrm{m}$ (Millipore) and pass through was collected (extracellular fraction). Bacteria retained in the filter were recovered with $1 \mathrm{ml}$ of $50 \mathrm{mM}$ phosphate buffer ( $\mathrm{pH}$ 7.2) and disrupted by sonication (intracellular fraction). Both fractions $(190 \mu \mathrm{l})$ were incubated separately with dihydrorhodamine- 123 to a final concentration of $5 \mu \mathrm{M}$ as previously described [49]. The fluorescent product, rhodamine-123, was measured by fluorescence detection with excitation and emission wavelengths of 500 and $536 \mathrm{~nm}$, respectively. $\mathrm{HOCl}$ and $\mathrm{H}_{2} \mathrm{O}_{2}$ uptake was determined as the extracellular/intracellular fluorescence ratio. The background fluorescence from a bacterial suspension not exposed to either of the toxic compounds was subtracted and results were normalized by protein concentration.

Proteoliposomes were prepared as described [50] with modifications [51]. For in vitro diffusion, proteoliposomes were incubated with $1.5 \mathrm{mM} \mathrm{H}_{2} \mathrm{O}_{2}$ or $530 \mu \mathrm{M} \mathrm{NaOCl}$ for $5 \mathrm{~min}$, vacuum filtered and pass through was recovered (extraliposomal fraction). Proteoliposomes were recovered from the filters with $2 \mathrm{ml}$ of $50 \mathrm{mM}$ phosphate buffer (pH 7.2) and disrupted by sonication (intraliposomal fraction).
Fluorescence was measured in both fractions as described above and $\mathrm{H}_{2} \mathrm{O}_{2}$ or $\mathrm{HOCl}$ uptake was determined as the extraliposomal/intraliposomal fluorescence ratio.

\section{Acknowledgments}

This work was supported by grants from FONDECYT \#1085131 and \#1120384 (to CPS), Universidad Andres Bello DI-34-11/R (to CPS), POSTDOC FONDECYT 3095013 (to ILC) and Universidad Andres Bello DI-50-09/R (to ILC). EHM and BC received doctoral fellowships by CONICYT and MECESUP UAB0802 additionally to EHM. We would like to thank Nicolás Pacheco for his assistance in the UFC experiments. The authors have declared that no competing interests exist. The funders had no role in study design, data collection and analysis, decision to publish, or preparation of the manuscript. Publication fees were covered by FONDECYT grant \# 1120384 and from Universidad Andres Bello DI-34-11/R (to CPS).

\section{Author details}

'Laboratorio de Microbiología Molecular, Facultad Ciencias Biológicas, Universidad Andres Bello, Santiago, Chile. ${ }^{2}$ The Vaccine Research Institute of San Diego, 3030 Bunker Hill Suite\# 203, San Diego, CA 92109, USA.

${ }^{3}$ Department of Pathology and Laboratory Medicine, D440 Medical Sciences I, University of California, Irvine, CA 92697, USA.

\section{Author's contributions}

EHM and CPS conceived the project. EHM, BC and ILC performed the experiments. FG and SPo conducted partial data analysis. EHM, ILC, MM and CPS wrote the paper. All authors read and approved the final manuscript.

Received: 2 February 2012 Accepted: 30 April 2012

Published: 30 April 2012

\section{References}

1. Fridovich I: The biology of oxygen radicals. Science 1978, 201:875-880.

2. Hassett D, Cohen M: Bacterial adaptation to oxidative stress: implications for pathogenesis and interaction with phagocytic cells. FASEB J 1989, 3:2574-2582.

3. Canvin J, Langford PR, Wilks KE, Kroll JS: Identification of sodC encoding periplasmic [CuZn]-superoxide dismutase in Salmonella. FEMS Microbiol Lett 1996, 136:215-220

4. Storz G, Imlay JA: Oxidative stress. Curr Opin Microbiol 1999, 2:188-194.

5. Thomas E: Myeloperoxidase: Hydrogen Peroxide, Chloride Antimicrobial System: Nitrogen-Chlorine Derivatives of Bacterial Components in Bactericidal Action Against Escherichia coli. Infect Immun 1979, 23:522-531.

6. Rosen H, Crowley J, Heinecke J: Human Neutrophils Use the Myeloperoxidase-Hydrogen Peroxide-Chloride System to Chlorinate but Not Nitrate Bacterial Proteins during Phagocytosis. J Biol Chem 2002, 277:30463-30468.

7. Hampton M, Kettle A, Winterbourn C: Inside the Neutrophil Phagosome: Oxidants, Myeloperoxidase and Bacterial Killing. Blood 1998, 92:3007-3017

8. Imlay J: Pathways of Oxidative Damage. Annu Rev Microbiol 2003, 57:395-418.

9. Seaver LC, Imlay JA: Hydrogen peroxide fluxes and compartmentalization inside growing Escherichia coli. J Bacterio/ 2001, 183:7182-7189.

10. Sousa-Lopes A, Antunes F, Cyrne L, Marinho HS: Decreased cellular permeability to $\mathrm{H}_{2} \mathrm{O}_{2}$ protects Saccharomyces cerevisiae cells in stationary phase against oxidative stress. FEBS Lett 2004, 578:152-156.

11. Leyer G, Johnson E: Acid Adaptation Sensitizes Salmonella Typhimurium to Hypochlorous Acid. Appl Environ Microbiol 1997, 63:461-467.

12. Calderón IL, Morales E, Caro NJ, Chahuán CA, Collao B, Gil F, Villareal JM, Ipinza F, Mora GC, Saavedra CP: Response regulator ArcA of Salmonella enterica serovar Typhimurium downregulates the expression of $\mathrm{OmpD}$, a porin facilitating uptake of hydrogen peroxide. Res Microbiol 2011, 162:214-222.

13. Nikaido $\mathrm{H}$ : Multidrug efflux pumps of gram-negative bacteria. J Bacteriol 1996, 178:5853-5859.

14. Shulz GE: $\beta$-barrel membrane proteins. Curr Opin Struct Biol 2000, 10:443-447.

15. Klebba P: The Porinologist. J. Bacteriol. 2005, 187:8232-8236. 
16. Albrecht R, Zeth $K$, Soding J, Lupas A, Linke D: Expression, crystallization and preliminary X-ray crystallographic studies of the outer membrane protein OmpW from Escherichia coli. Acta Cryst. 2006, 62:415-418.

17. Hong H, Patel DR, Tamm LK, Van den Berg B: The outer membrane protein OmpW forms an eight-stranded beta-barrel with a hydrophobic channel. J Biol Chem 2006, 281:7568-7577.

18. Jalajakumari MB, Manning PA: Nucleotide sequence of the gene ompW, encoding a $22 \mathrm{kDa}$ immunogenic outer membrane protein of Vibrio cholerae. Nucleic Acids Res 1990, 18:2180.

19. Bisweswar N, Nandy RK, Sarkar A, Ghose AC: Structural features, properties and regulation of the outer-membrane protein $\mathrm{W}(\mathrm{OmpW})$ of Vibrio cholerae. Microbiology 2005, 151:2975-2986

20. Gil F, Ipinza P, Fuentes J, Fumeron R, Villareal JM, Aspée A, Mora GC, Vásquez CC, Saavedra C: The ompW (porin) gene mediates methyl viologen (paraquat) efflux in Salmonella enterica serovar Typhimurium. Res Microbiol 2007, 158:529-536.

21. Wang S, Phillippy A, Deng K, Rui X, Li Z, Tortorello ML, Zhang W: Transcriptomic Responses of Salmonella enteric Serovars Enteritidis and Typhimurium to Chlorine-Based Oxidative Stress. Appl Environ Microbiol 2010, 76:5013-5024.

22. Christman MF, Morgan RW, Jacobson FS, Ames BN: Positive control of a regulon for defenses against oxidative stress and some heat-shock proteins in Salmonella typhimurium. Cell 1985, 41:753-762.

23. Greenberg JT, Monach P, Chou JH, Josephy PD, Demple B: Positive control of a global antioxidant defense regulon activated by superoxide-generating agents in Escherichia coli. Proc Natl Acad Sci 1990, 87:6181-6185

24. Lu S, Killoran PB, Fang FC, Riley LW: The global regulator ArcA controls resistance to reactive nitrogen and oxygen intermediates in Salmonella enterica serovar Enteritidis. Infect Immun 2002, 70:451-461.

25. Wong SM, Alugupalli KR, Ram S, Akerley BJ: The ArcA regulon and oxidative stress resistance in Haemophilus influenzae. Mol Microbiol 2007 64:1375-1390.

26. Loui C, Chang AC, Lu S: Role of the ArCAB two-component system in the resistance of Escherichia coli to reactive oxygen stress. BMC Microbiol 2009, 9:183.

27. Evans MR, Fink RC, Vazquez-Torres A, Porwollik S, Jones-Carson J, McClelland $M$, Hassan HM: Analysis of the ArcA regulon in anaerobically grown Salmonella enterica sv. Typhimurium. BMC Microbiol 2011, 21:11-58.

28. luchi S, Matsuda Z, Fujiwara T, Lin EC: The $\operatorname{arcB}$ gene of Escherichia coli encodes a sensor-regulator protein for anaerobic repression of the arc modulon. Mol Microbiol 1990, 4:715-727.

29. Malpica R, Franco B, Rodriguez C, Kwon O, Georgellis D: Identification of a quinone-sensitive redox switch in the ArcB sensor kinase. Proc Natl Acad Sci 2004, 101:13318-13323.

30. Peña-Sandoval G, Georgellis D: The ArcB Sensor Kinase of Escherichia coli Autophosphorylates by an Intramolecular Reaction. J Bacteriol 2010, 192:1735-1739.

31. Iuchi S, Lin EC: Purification and phosphorylation of the Arc regulatory components of Escherichia coli. J Bacteriol 1992, 174:5617-5623.

32. Georgellis D, Lynch AS, Lin EC: In vitro phosphorylation study of the arc two-component signal transduction system of Escherichia coli. J Bacteriol 1997, 179:5429-5435.

33. Kwon O, Georgellis D, Lin EC: Phosphorelay as the Sole Physiological Route of Signal Transmission by the Arc Two-Component system of Escherichia coli. J Bacteriol 2000, 182:3858-3862.

34. Lynch AS, Lin EC: Transcriptional control mediated by the ArcA two-component response regulator protein of Escherichia coli: characterization of DNA binding at target promoters. J Bacteriol 1996, 178:6238-6249

35. Jeon Y, Lee Y, Han J, Kim J, Hwang D: Multimerization of Phosphorylated and Non-phosphorylated ArcA is Necessary for the Response Regulator Function of the Arc Two-Component Signal Transduction System. J Biol Chem 2001, 276:40873-40879.

36. Georgellis D, Kwon O, Lin EC: Quinones as the Redox Signal for the Arc Two-Component System of Bacteria. Science 2001, 292:2314-2316.

37. Alexeeva S, Hellingwerf K, Mattos JT: Requirement of ArcA for Redox Regulation in Escherichia coli under Microaerobic but Not Anaerobic or Aerobic Conditions. J Bacterio/ 2003, 185:204-209.

38. Bekker M, Alexeeva S, Laan W, Sawers G, Mattos JT, Hellingwerf K: The ArcBA Two-Component System of Escherichia coli Is Regulated by the
Redox State of both the Ubiquinone and the Menaquinone Pool. $J$ Bacteriol 2010, 191:746-754.

39. Rolfe MD, Ter Beek A, Graham Al, Trotter EW: Shahzad Asif HM, SysMO-SUMO, Sanguinetti G, Teixeira de Mattos J, Poole RK, Green J: Transcript Profiling and Inference of Escherichia coli K-12 ArcA Activity across the Range of Physiologically Relevant Oxygen Concentrations. J Biol Chem 2011, 286:10147-10154.

40. De Spiegeleer P, Sermon J, Vanoirbeek K, Aertsen A, Michiels CW: Role of porins in sensitivity of Escherichia coli to antibacterial activity of the lactoperoxidase enzyme system. Appl Environ Microbiol 2005 71:3512-3518.

41. Münch R, Hiller K, Grote A, Scheer M, Klein J, Schobert M, Jahn D: Virtual Footprint and PRODORIC: an integrative framework for regulon prediction in prokaryotes. Bioinformatics 2005, 21:4187-4189.

42. Gil F, Hernández-Lucas I, Polanco R, Pacheco N, Collao B, Villareal JM, Nardocci G, Calva E, Saavedra CP: SoxS regulates the expression of the Salmonella enterica serovar Typhimurium ompW gene. Microbiology 2009 155:2490-2497.

43. Matsubara M, Kitaoka SI, Takeda SI, Mizuno T: Tuning of the porin expression under anaerobic growth conditions by his-to-Asp cross-phosphorelay through both the EnvZ-osmosensor and ArcB-anaerosensor in Escherichia coli. Genes Cells 2000, 5:555-569.

44. Dukan S, Dadon S, Smulski DR, Belkin S: Hypochlorous Acid Activates the Heat Shock and soxRS Systems of Escherichia coli. Appl Environ Microbiol 1996, 62:4003-4008.

45. Matsushika A, Mizuno T: A dual-signaling mechanism mediated by the ArcB hybrid sensor kinase containing the histidine-containing phosphotransfer domain in Escherichia coli. J Bacteriol 1998, 180:3973-3977.

46. Datsenko KA, Wanner BL: One-step inactivation of chromosomal genes in Escherichia coli K-12 using PCR products. Proc Natl Acad Sci 2000, 97:6640-6645.

47. Pfaffl MW: A new mathematical model for relative quantification in real-time RT-PCR. Nucleic Acids Res 2001, 29:e45.

48. Mika F, Hengge R: A btwo-component phosphotransfer network involving ArcB, ArcA, and RssB coordinates synthesis and proteolysis of $\sigma \mathrm{S}$ (RpoS) in E. coli. Genes Dev 2005, 19:2770-2781.

49. Rezk BM, Haenen G, van der Vijgh W, Bast A: Lipoic Acid Protects Efficiently Only against a Specific Form of Peroxynitrite-induced Damage. J Biol Chem 2004, 279:9693-9697

50. Nikaido H, Rosenberg EY: Porin channels in Escherichia coli: studies with liposomes reconstituted from purified proteins. J Bacteriol 1983, 153:241-252.

51. Cubillos MA, Lissi EA, Abuin EB: Kinetics of peroxidation of linoleic acid incorporated into DPPC vesicles initiated by the thermal decomposition of 2,2'-azobis(2-amidinopropane) dihydrochloride. Chem Phys Lipids 2001, $112: 41-46$.

doi:10.1186/1471-2180-12-63

Cite this article as: Morales et al:: Hypochlorous acid and hydrogen peroxide-induced negative regulation of Salmonella enterica serovar Typhimurium ompW by the response regulator ArcA. BMC Microbiology 2012 12:63.

\section{Submit your next manuscript to BioMed Central and take full advantage of:}

- Convenient online submission

- Thorough peer review

- No space constraints or color figure charges

- Immediate publication on acceptance

- Inclusion in PubMed, CAS, Scopus and Google Scholar

- Research which is freely available for redistribution 